\title{
Effect of Naphthalene Acetic Acid and Colour Poly Wrappers on Rooting, Survival and Economics of Air Layring of Guava (Psidium guajava L.) cv. Gwalior 27
}

\author{
Vikas Mandloi*, Rajesh Lekhi, Devendra Vishvkarma and Amit Patel \\ Department of Horticulture, College of Agriculture, Rajmata Vijayaraje Scindia Krishi \\ Vishwa Vidyalaya, Gwalior, (M.P.), India
}

*Corresponding author

\section{A B S T R A C T}

\section{Keywords \\ Guava, NAA, Poly wrapper, Rooting, Survival, \\ Economics and Air layering. \\ Article Info \\ Accepted: \\ 18 August 2019 \\ Available Online: \\ 10 September 2019}

The experiment was carried out to "Effect of NAA (foliar spray) and colour poly wrappers on rooting, survival and economics of air-layering of guava (Psidium guajava $\mathrm{L}$.) cv. Gwalior 27" during the season of Kharif 2016-17 at the Horticulture nursery, Department of Horticulture, College of Agriculture, Rajmata Vijayaraje Scindia Krishi Vishwa Vidyalaya, Gwalior, (M.P.). Results revealed that significantly maximum rooting such as number of primary roots per layer (7.46) and secondary roots per layer (9.55), length of primary roots $(8.07 \mathrm{~cm})$ and secondary roots $(9.04 \mathrm{~cm})$, dry weight of roots per layer $(0.209 \mathrm{~g})$, rooting percentage $(61.12 \%)$ and survival percentage $(47.31 \%)$ in air layers of guava was recorded with the application of $125 \mathrm{ppm}$ NAA $\left(\mathrm{N}_{4}\right)$. Black poly wrapper $\left(\mathrm{W}_{2}\right)$ exhibited significantly maximum number of primary roots per layer (6.57) and secondary roots per layer $(9.21)$, length of primary roots $(9.74 \mathrm{~cm})$ and secondary roots $(10.02 \mathrm{~cm})$, dry weight of roots per layer $(0.168 \mathrm{~g})$, rooting percentage $(54.79 \%)$ and survival percentage $(43.75 \%)$ at 60 days after layering. Interaction was also significantly maximum under the treatment combination of $\mathrm{N}_{4} \mathrm{~W}_{2}$ (NAA @ $125 \mathrm{ppm}+$ Black poly wrapper) over the $\mathrm{N}_{1} \mathrm{~W}_{1}$ (NAA @ $50 \mathrm{ppm}+$ White poly wrapper). number of primary roots per layer (8.55) and secondary roots per layer (10.85), length of primary roots $(10.49 \mathrm{~cm})$ and secondary roots $(10.77 \mathrm{~cm})$, dry weight of roots per layer $(0.247$ g),rooting percentage $(65.63 \%)$ and survival percentage $(50.93 \%)$. The maximum net return of Rs 14559.00 and highest cost benefit ratio 1: 3.51 was recorded in treatment $\mathrm{N}_{4} \mathrm{~W}_{2}$ (NAA@125 ppm + Black poly wrapper).

\section{Introduction}

Guava (Psidium guajava L.), is one of the most popular fruits grown in tropical, subtropical and some parts of arid regions of India. It is also a cheap and very rich source of
vitamin-C, carbohydrate, iron, fat and contains a fair amount of calcium and phosphorus as well. These qualities make guava an important and one of the most popular fruits of India. Guava fruits are rich in pectin content, hence it is extensively used in preparation of jelly. 
Besides, its diabetic value, the fruit also is used in preparing cheese, butter, paste, juice, juice concentrate, powder, canned slice/shell, nectar, puree and ice cream. India is the leading producer of guava in the world. Total area and production of guava in India is about 262 thousand hectares and 3648 thousand MT, respectively and productivity of guava is 13.92 MT/ha. Madhya Pradesh ranks second in productivity with $17.27 \mathrm{MT} / \mathrm{ha}$ and it is grown 30.31 thousand hectares and produce 523.75 thousand MT. (Anonymous, 2017).

Air- layring is an easy method of propagation of this crop. Auxins particularly IBA and NAA have been reported to induce rooting in many of the plant species with varied success. The response of different growth substances to percent success varied from species to species with changing physiological and environmental conditions. Most of the workers have reported IBA and NAA as better growth regulators than others for inducing rooting in cuttings and air- layring due to their stable nature. Air layering was reported to have given good results (Hartmann and Kester, 1972). Air layering with the help of growth substances is more efficacious and is the best method of vegetative propagation of guava as reported by Mujumdar and Mukherjee (1968). Plastic materials are also widely used in the horticultural industry viz. in glass house propagation of cuttings, for mass propagation in bud grafting and air layering. Polythene was discovered by scientist in the United Kingdom in 1933 and polythene sheet are now available in different gauges and color. Polythene wrapper has properties which in some aspects make in similar to the outer skin of plants. It is water proof, transmits light and allows gaseous exchange of oxygen and carbondioxide and low transmission of water vapour.

Keeping in view an experiment was conducted to identify the best concentration of the growth regulators and colour of poly wrapper which can induce better rooting in air-layers and can improve the survival of guava after detachment.

\section{Materials and Methods}

The experiment was carried out to "Effect of different concentrations of NAA (foliar spray) and different colour poly wrappers on airlayering of guava (Psidium guajava L.) cv. Gwalior 27" during the season of Kharif 2016-17 at the Horticulture nursery, Department of Horticulture, College of Agriculture, Rajmata Vijayaraje Scindia Krishi Vishwa Vidyalaya, Gwalior, (M.P.). The experimental material for the present investigation was comprised of 12 treatment combinations viz., foliar sprays of four levels of NAA i.e. 50, 75, 100 and $125 \mathrm{ppm}$ and three levels of poly wrappers i.e. white, black and blue were used at the time of layering and were replicated three times in Asymmetrical Factorial Randomized Complete Block Design. On the selected branches a ring bark of about 2.0 $\mathrm{cm}$ size is removed by budding knife just below the bud without injuring the under lying woody xylem portion. The as par treatment NAA solution was applied uniformly on all sides of the upper cut of the ring with camel hair brush. After application of growth regulators cut portions were covered with rooting media containing a mixture of farm yard manure and field soil in 1:1 ratio and wrapped with three coloured polythene film (400 gauze) and tied with sutli. The air layers were detached by making a sharp cut with secateurs just below the cut after 65 days of operation. Then polythene cover was removed after dipping them in water for avoiding injury to the roots, and immediately air layers were planted in polythene bags. The observation on number of primary roots per layer, length of primary root $(\mathrm{cm})$, number of secondary roots per layer, length of secondary 
root $(\mathrm{cm})$, dry weight of roots per layer $(\mathrm{g})$, rooting percentage, survival percentage were observed and to estimate the economics of the treatments. Observations were recorded on the basis of five random competitive layers and plants selected in each treatment separately for root and shoot characteristics at 30 and 60 days after layering and planting in polybag respectively and were evaluated as per standard procedure. The data were statistically analyses to find out overall total variability present in the material by following procedure as suggested by Panse and Sukhatme (1985).

\section{Results and Discussion}

The results revealed that NAA concentrations, colour poly wrappers and their interaction exhibited a significant effect on root parameters. The significantly maximum 4.81 and 7.46 primary roots per layer were recorded in treatment $\mathrm{N}_{4}$ (NAA @ 125 ppm) followed by $\mathrm{N}_{3}$ (NAA @ 100 ppm) 4.26 and 5.89, while, it was recorded minimum 2.85 and 4.33 primary roots per layer at 30 and 60 days after layering, respectively (Table 1). These findings are in agreement with the findings of Tomar et al., (1999a), Tomar (2011), Patel et al., (2012) and Singh and Pathak (2012).

Black poly wrapper $\left(\mathrm{W}_{2}\right)$ was significantly superior and was recorded maximum 4.90 and 6.57 primary roots per layer as compared to white poly wrapper $\left(\mathrm{W}_{1}\right)$ (3.03 and 4.82 primary roots per layer) at 30 and 60 days after layering, respectively.

Interaction effects of different levels of NAA and colour poly wrappers, the treatment combination of $\mathrm{N}_{4} \mathrm{~W}_{2}$ (NAA @ $125 \mathrm{ppm}+$ Black poly wrapper) was recorded significantly maximum 6.0 and 8.55 primary roots per layer followed by $\mathrm{N}_{3} \mathrm{~W}_{2}$ (NAA @
100 ppm + Black poly wrapper) (5.64 and 7.54) and $\mathrm{N}_{4} \mathrm{~W}_{3}$ (NAA @ $125 \mathrm{ppm}+$ Blue poly wrapper) (4.48 and 7.23) at 30 and 60 days after layering, respectively. While, the minimum 2.17 and 3.88 primary roots per layer were recorded in the treatment combination of $\mathrm{N}_{1} \mathrm{~W}_{1}$ (NAA @ 50 ppm + White poly wrapper) at 30 and 60 days after layering, respectively. These findings are in agreement with the findings of Singh (2001) and Yeboah et al., (2014).

The significantly maximum 4.80 and $8.07 \mathrm{~cm}$ length of primary root were recorded in treatment $\mathrm{N}_{4}$ (NAA@125 ppm) followed by $\mathrm{N}_{3}$ (NAA @ 100 ppm) 4.55 and $7.62 \mathrm{~cm}$ at 30 and 60 days after layering, respectively and which were at par with each other at 30 days after layering. While, it was recorded minimum 3.52 and $6.39 \mathrm{~cm}$ at 30 and 60 days after layering, respectively(Table 1). These findings are in agreement with the findings of Tomar et al., (1999a), Tomar (2011) and Patel et al., (2012).

Black poly wrapper $\left(\mathrm{W}_{2}\right)$ was significantly superior and was recorded maximum 5.57 and $9.74 \mathrm{~cm}$ length of primary root as compared to white poly wrapper $\left(\mathrm{W}_{1}\right)(3.15$ and $4.98 \mathrm{~cm})$ at 30 and 60 days after layering, respectively.

The treatment combination of $\mathrm{N}_{4} \mathrm{~W}_{2}$ (NAA @ 125 ppm + Black poly wrapper) was recorded significantly maximum 6.13 and $10.49 \mathrm{~cm}$ length of primary root followed by $\mathrm{N}_{3} \mathrm{~W}_{2}$ (NAA @ 100 ppm + Black poly wrapper) (5.83 and $10.15 \mathrm{~cm}$ ) and $\mathrm{N}_{4} \mathrm{~W}_{3}$ (NAA @ 125 ppm + Blue poly wrapper) (4.63 and $7.96 \mathrm{~cm})$, while, the minimum 2.62 and $4.27 \mathrm{~cm}$ length of primary root were recorded in the treatment combination of $\mathrm{N}_{1} \mathrm{~W}_{1}$ (NAA @ 50 ppm + White poly wrapper) at 30 and 60 days after layering, respectively. These 
findings are in agreement with the findings of Singh (2001) and Yeboah et al., (2014).

The treatment $\mathrm{N}_{4}$ (NAA@ 125 ppm) was recorded significantly maximum 6.47 and 9.55 secondary roots per layer followed by $\mathrm{N}_{3}$ (NAA @ 100 ppm) 5.94 and 8.56 at 30 and 60 days after layering, respectively and which were at par with each other at 30 days after layering. While, it was recorded minimum 5.08 and 6.38 secondary roots per layer at 30 and 60 days after layering, respectively(Table 1). These findings are in agreement with the findings of Tomar et al., (1999a), Tomar (2011), Patel et al., (2012) and Singh and Pathak (2012).

Black poly wrapper $\left(\mathrm{W}_{2}\right)$ was significantly superior and was recorded maximum 6.59 and 9.21 secondary roots per layer as compared to white poly wrapper $\left(\mathrm{W}_{1}\right)(5.20$ and 7.01 secondary roots per layer) at 30 and 60 days after layering, respectively.

The treatment combination of $\mathrm{N}_{4} \mathrm{~W}_{2}$ (NAA @ 125 ppm + Black poly wrapper) was recorded maximum 7.81 and 10.85 secondary roots per layer followed by $\mathrm{N}_{3} \mathrm{~W}_{2}$ (NAA @ 100 ppm + Black poly wrapper) (6.90 and 9.84) and $\mathrm{N}_{4} \mathrm{~W}_{3}$ (NAA @ $125 \mathrm{ppm}+$ Blue poly wrapper) (5.84 and 9.38), while, the minimum 4.71 and 5.51 secondary roots per layer were recorded in the treatment combination of $\mathrm{N}_{1} \mathrm{~W}_{1}$ (NAA @ $50 \mathrm{ppm}+$ White poly wrapper) at 30 and 60 days after layering, respectively. These findings are in agreement with the findings of Singh (2001) and Yeboah et al., (2014).

Significantly maximum 5.40 and 9.04 $\mathrm{cm}$ length of secondary root were recorded in treatment $\mathrm{N}_{4}$ (NAA @ 125 ppm) followed by $\mathrm{N}_{3}$ (NAA @ 100 ppm) (4.73 and $8.07 \mathrm{~cm})$, while, it was recorded minimum 3.69 and $6.57 \mathrm{~cm}$ at 30 and 60 days after layering, respectively. Similar findings were also reported by Tomar et al., (1999a) and Patel et al., (2012).

Black poly wrapper $\left(\mathrm{W}_{2}\right)$ was significantly superior and was recorded maximum 6.05 and $10.02 \mathrm{~cm}$ length of secondary root as compared to white poly wrapper $\left(\mathrm{W}_{1}\right)(3.25$ and $5.16 \mathrm{~cm}$ ) at 30 and 60 days after layering, respectively.

Treatment combination of $\mathrm{N}_{4} \mathrm{~W}_{2}$ (NAA @ 125 ppm + Black poly wrapper) was recorded significantly maximum 6.80 and $10.77 \mathrm{~cm}$ length of secondary root at par with $\mathrm{N}_{3} \mathrm{~W}_{2}$ (NAA @ 100 ppm + Black poly wrapper) (6.57 and $10.57 \mathrm{~cm}$ ) and $\mathrm{N}_{4} \mathrm{~W}_{3}$ (NAA @ 125 ppm + Blue poly wrapper) (5.40 and 10.38 $\mathrm{cm}$ ), while, the minimum 2.73 and $4.40 \mathrm{~cm}$ length of secondary root were recorded in the treatment combination of $\mathrm{N}_{1} \mathrm{~W}_{1}$ (NAA @ 50 ppm + White poly wrapper) at 30 and 60 days after layering, respectively(Table 1). These findings are in agreement with the findings of Singh (2001) and Yeboah et al., (2014).

This may be due to decomposed organic material improve soil fertility by increasing soil aeration, water holding capacity and water infiltration and lower surface crusting resulted in maximum root growth and root length of primary and secondary root.

Application of NAA $125 \mathrm{ppm}\left(\mathrm{N}_{4}\right)$ was significantly superior and recorded maximum 0.098 and $0.209 \mathrm{~g}$ dry weight of roots followed by $\mathrm{N}_{3}$ (NAA $100 \mathrm{ppm}$ ) (0.060 and $0.160 \mathrm{~g}$ ) as compared to other treatment, while, it was observed lowest 0.028 and 0.077 $\mathrm{g}$ dry weight of roots in the treatment NAA 50 ppm $\left(\mathrm{N}_{1}\right)$ at 30 and 60 days after layering, respectively(Table 2 ). 
Table.1 Effect of different concentrations of NAA and colour poly wrappers on number of primary and secondary roots per layer and length of primary and secondary root $(\mathrm{cm})$ in air layers of guava

\begin{tabular}{|c|c|c|c|c|c|c|c|c|c|}
\hline \multirow[t]{2}{*}{$\begin{array}{l}\text { Treat. } \\
\text { Symb. }\end{array}$} & \multirow[t]{2}{*}{ Treatment } & \multicolumn{2}{|c|}{$\begin{array}{l}\text { No. of primary } \\
\text { roots per layer }\end{array}$} & \multicolumn{2}{|c|}{$\begin{array}{l}\text { Length of primary } \\
\text { root }(\mathbf{c m})\end{array}$} & \multicolumn{2}{|c|}{$\begin{array}{l}\text { No. of secondary } \\
\text { roots per layer }\end{array}$} & \multicolumn{2}{|c|}{$\begin{array}{l}\text { Length of secondary } \\
\text { root }(\mathrm{cm})\end{array}$} \\
\hline & & 30 Days & 60 Days & 30 Days & 60 Days & 30 Days & 60 Days & 30 Days & 60 Days \\
\hline $\mathbf{N}_{1}$ & NAA@50ppm & 2.85 & 4.33 & 3.52 & 6.39 & 5.08 & 6.38 & 3.69 & 6.57 \\
\hline $\mathbf{N}_{2}$ & NAA@75 ppm & 3.32 & 4.78 & 4.08 & 6.97 & 5.39 & 7.29 & 4.45 & 7.42 \\
\hline $\mathbf{N}_{3}$ & NAA@100 ppm & 4.26 & 5.89 & 4.55 & 7.62 & 5.94 & 8.56 & 4.73 & 8.07 \\
\hline $\mathbf{N}_{4}$ & NAA@125 ppm & 4.81 & 7.46 & 4.80 & 8.07 & 6.47 & 9.55 & 5.40 & 9.04 \\
\hline & SEm \pm & 0.12 & 0.02 & 0.11 & 0.02 & 0.19 & 0.01 & 0.11 & 0.10 \\
\hline & $\mathrm{CD}$ at $5 \%$ level & 0.36 & 0.06 & 0.34 & 0.06 & 0.58 & 0.04 & 0.33 & 0.30 \\
\hline $\mathbf{W}_{1}$ & White poly wrapper & 3.03 & 4.82 & 3.15 & 4.98 & 5.20 & 7.01 & 3.25 & 5.16 \\
\hline $\mathbf{W}_{2}$ & Black poly wrapper & 4.90 & 6.57 & 5.57 & 9.74 & 6.59 & 9.21 & 6.05 & 10.02 \\
\hline $\mathbf{W}_{3}$ & Blue poly wrapper & 3.51 & 5.45 & 3.99 & 7.07 & 5.37 & 7.62 & 4.41 & 8.15 \\
\hline & $\mathrm{SEm} \pm$ & 0.11 & 0.02 & 0.10 & 0.03 & 0.17 & 0.01 & 0.09 & 0.09 \\
\hline & $\mathrm{CD}$ at $5 \%$ level & 0.32 & 0.05 & 0.30 & 0.09 & 0.51 & 0.03 & 0.28 & 0.26 \\
\hline $\mathbf{N}_{1} \mathbf{W}_{1}$ & NAA@50 ppm + White poly wrapper & 2.17 & 3.88 & 2.62 & 4.27 & 4.71 & 5.51 & 2.73 & 4.40 \\
\hline $\mathbf{N}_{1} \mathbf{W}_{2}$ & NAA@50 ppm + Black poly wrapper & 3.81 & 5.03 & 4.75 & 8.73 & 5.64 & 7.55 & 4.95 & 8.92 \\
\hline $\mathbf{N}_{1} \mathbf{W}_{3}$ & NAA@50 ppm + Blue poly wrapper & 2.58 & 4.06 & 3.18 & 6.17 & 4.89 & 6.08 & 3.40 & 6.38 \\
\hline $\mathbf{N}_{2} \mathbf{W}_{1}$ & NAA@75 ppm + White poly wrapper & 2.67 & 4.30 & 2.98 & 4.62 & 4.98 & 6.30 & 2.80 & 4.78 \\
\hline $\mathbf{N}_{2} \mathbf{W}_{2}$ & NAA@75 ppm + Black poly wrapper & 4.14 & 5.48 & 5.57 & 9.59 & 6.01 & 8.58 & 5.87 & 9.83 \\
\hline $\mathbf{N}_{2} \mathbf{W}_{3}$ & NAA@75 ppm + Blue poly wrapper & 3.13 & 4.58 & 3.70 & 6.69 & 5.19 & 7.00 & 4.68 & 7.65 \\
\hline $\mathrm{N}_{3} \mathrm{~W}_{1}$ & NAA@100 ppm + White poly wrapper & 3.30 & 4.81 & 3.38 & 5.27 & 5.35 & 7.81 & 3.48 & 5.47 \\
\hline $\mathbf{N}_{3} \mathbf{W}_{2}$ & NAA@100 ppm + Black poly wrapper & 5.64 & 7.54 & 5.83 & 10.15 & 6.90 & 9.84 & 6.57 & 10.57 \\
\hline $\mathbf{N}_{3} \mathbf{W}_{3}$ & NAA@100 ppm + Blue poly wrapper & 3.83 & 5.63 & 4.43 & 7.44 & 5.56 & 8.01 & 4.15 & 8.18 \\
\hline $\mathbf{N}_{4} \mathbf{W}_{1}$ & NAA@125 ppm + White poly wrapper & 3.97 & 6.30 & 3.63 & 5.76 & 5.75 & 8.41 & 4.00 & 5.97 \\
\hline $\mathbf{N}_{4} \mathbf{W}_{2}$ & NAA@125 ppm + Black poly wrapper & 6.00 & 8.55 & 6.13 & 10.49 & 7.81 & 10.85 & 6.80 & 10.77 \\
\hline $\mathbf{N}_{4} \mathbf{W}_{3}$ & NAA@125 ppm + Blue poly wrapper & 4.48 & 7.23 & 4.63 & 7.96 & 5.84 & 9.38 & 5.40 & 10.38 \\
\hline & SEm \pm & 0.21 & 0.03 & 0.20 & 0.03 & 0.34 & 0.02 & 0.19 & 0.18 \\
\hline & $\mathrm{CD}$ at $5 \%$ level & N.S. & 0.10 & 0.59 & 0.09 & N.S. & 0.07 & 0.57 & 0.53 \\
\hline
\end{tabular}


Table.2 Effect of different concentrations of NAA and colour poly wrappers on dry weight of roots/ layer, rooting and survival per cent in air layers of guava

\begin{tabular}{|c|c|c|c|c|c|}
\hline \multirow{2}{*}{$\begin{array}{l}\text { Treat. } \\
\text { Symb. }\end{array}$} & \multirow[t]{2}{*}{ Treatment } & \multicolumn{2}{|c|}{ Dry weight of roots/ layer (g) } & \multirow{2}{*}{$\begin{array}{c}\text { Rooting } \\
\text { percentage }\end{array}$} & \multirow{2}{*}{$\begin{array}{c}\text { Survival } \\
\text { percentage }\end{array}$} \\
\hline & & 30 Days & 60 Days & & \\
\hline $\mathbf{N}_{1}$ & NAA@50 ppm & 0.028 & 0.077 & 35.39 & 33.52 \\
\hline $\mathbf{N}_{2}$ & NAA@75 ppm & 0.047 & 0.113 & 46.74 & 38.36 \\
\hline $\mathbf{N}_{3}$ & NAA@ 100 ppm & 0.060 & 0.160 & 51.53 & 40.74 \\
\hline $\mathbf{N}_{4}$ & NAA@125 ppm & 0.098 & 0.209 & 61.12 & 47.31 \\
\hline & SEm \pm & 0.003 & 0.003 & 0.40 & 0.48 \\
\hline & $\mathrm{CD}$ at $5 \%$ level & 0.009 & 0.007 & 1.14 & 1.43 \\
\hline $\mathbf{W}_{1}$ & White poly wrapper & 0.038 & 0.111 & 42.64 & 37.10 \\
\hline $\mathbf{W}_{2}$ & Black poly wrapper & 0.078 & 0.168 & 54.79 & 43.75 \\
\hline $\mathbf{W}_{3}$ & Blue poly wrapper & 0.058 & 0.140 & 48.66 & 39.10 \\
\hline & $\mathrm{SEm} \pm$ & 0.003 & 0.002 & 0.35 & 0.42 \\
\hline & $\mathrm{CD}$ at $5 \%$ level & 0.008 & 0.006 & 0.99 & 1.23 \\
\hline $\mathbf{N}_{1} \mathbf{W}_{1}$ & NAA@ 50 ppm + White poly wrapper & 0.013 & 0.057 & 30.57 & 32.30 \\
\hline $\mathbf{N}_{1} \mathbf{W}_{2}$ & NAA@ 50 ppm + Black poly wrapper & 0.037 & 0.097 & 42.00 & 35.13 \\
\hline $\mathbf{N}_{1} \mathbf{W}_{3}$ & NAA@ 50 ppm + Blue poly wrapper & 0.033 & 0.077 & 33.60 & 33.13 \\
\hline $\mathbf{N}_{2} \mathbf{W}_{1}$ & NAA@75 ppm + White poly wrapper & 0.037 & 0.087 & 37.93 & 34.90 \\
\hline $\mathbf{N}_{2} \mathbf{W}_{2}$ & NAA@75 ppm + Black poly wrapper & 0.057 & 0.140 & 53.47 & 42.77 \\
\hline $\mathbf{N}_{2} \mathbf{W}_{3}$ & NAA@75 ppm + Blue poly wrapper & 0.047 & 0.113 & 48.83 & 37.40 \\
\hline $\mathbf{N}_{3} \mathbf{W}_{1}$ & NAA@ @100 ppm + White poly wrapper & 0.047 & 0.133 & 45.30 & 36.50 \\
\hline $\mathbf{N}_{3} \mathbf{W}_{2}$ & NAA @ 100 ppm + Black poly wrapper & 0.097 & 0.213 & 60.97 & 46.30 \\
\hline $\mathbf{N}_{\mathbf{3}} \mathbf{W}_{\mathbf{3}}$ & NAA@100 ppm + Blue poly wrapper & 0.057 & 0.157 & 51.23 & 39.57 \\
\hline $\mathbf{N}_{4} \mathbf{W}_{1}$ & NAA@125 ppm + White poly wrapper & 0.057 & 0.167 & 56.77 & 44.70 \\
\hline $\mathbf{N}_{4} \mathbf{W}_{2}$ & NAA@125 ppm + Black poly wrapper & 0.140 & 0.247 & 65.63 & 50.93 \\
\hline $\mathbf{N}_{4} \mathbf{W}_{3}$ & NAA@125 ppm + Blue poly wrapper & 0.077 & 0.190 & 58.07 & 46.17 \\
\hline & SEm \pm & 0.005 & 0.004 & 0.70 & 0.73 \\
\hline & $\mathrm{CD}$ at $5 \%$ level & 0.015 & 0.013 & 1.97 & 2.47 \\
\hline
\end{tabular}


Table.3 Economics of different concentrations of NAA and colour poly wrappers in air layers of guava

\begin{tabular}{|l|c|c|c|c|c|}
\hline $\begin{array}{c}\text { Treat. } \\
\text { Sym. }\end{array}$ & $\begin{array}{c}\text { Survival of } \\
\text { air layers }\end{array}$ & $\begin{array}{c}\text { Gross income } \\
(\mathbf{R s})^{*}\end{array}$ & $\begin{array}{c}\text { Expenditure } \\
(\mathbf{R s})\end{array}$ & $\begin{array}{c}\text { Net return } \\
(\mathbf{R s})\end{array}$ & $\mathbf{C}:$ B ratio \\
\hline $\mathrm{N}_{1} \mathrm{~W}_{1}$ & 323 & 12920 & 5900.40 & 7019.60 & $1: 2.19$ \\
\hline $\mathrm{N}_{1} \mathrm{~W}_{2}$ & 351 & 14040 & 5800.40 & 8239.60 & $1: 2.42$ \\
\hline $\mathrm{N}_{1} \mathrm{~W}_{3}$ & 331 & 13240 & 5850.40 & 7389.60 & $1: 2.26$ \\
\hline $\mathrm{N}_{2} \mathrm{~W}_{1}$ & 349 & 13960 & 5900.60 & 8059.40 & $1: 2.37$ \\
\hline $\mathrm{N}_{2} \mathrm{~W}_{2}$ & 428 & 17120 & 5800.60 & 11319.40 & $1: 2.95$ \\
\hline $\mathrm{N}_{2} \mathrm{~W}_{3}$ & 374 & 14960 & 5850.60 & 9109.40 & $1: 2.56$ \\
\hline $\mathrm{N}_{3} \mathrm{~W}_{1}$ & 365 & 14600 & 5900.80 & 8699.20 & $1: 2.47$ \\
\hline $\mathrm{N}_{3} \mathrm{~W}_{2}$ & 462 & 18480 & 5800.80 & 12679.20 & $1: 3.19$ \\
\hline $\mathrm{N}_{3} \mathrm{~W}_{3}$ & 396 & 15840 & 5850.80 & 9989.20 & $1: 2.71$ \\
\hline $\mathrm{N}_{4} \mathrm{~W}_{1}$ & 447 & 17880 & 5901.00 & 11979.00 & $1: 3.03$ \\
\hline $\mathrm{N}_{4} \mathrm{~W}_{2}$ & 509 & 20360 & 5801.00 & 14559.00 & $1: 3.51$ \\
\hline $\mathrm{N}_{4} \mathrm{~W}_{3}$ & 463 & 18520 & 5851.00 & 12669.00 & $1: 3.17$ \\
\hline
\end{tabular}

Note: Sale rate of plants Rs. 40/plant 
Similar findings were also reported by Tomar et al., (1999a), Tomar (2011) and Patel et al., (2012).

Significantly maximum 0.078 and 0.168 g dry weight of roots was observed under the treatment $\mathrm{W}_{2}$ (Black poly wrapper) and lowest 0.038 and $0.111 \mathrm{~g}$ dry weight of roots in the treatment $\mathrm{W}_{1}$ (white poly wrapper) at 30 and 60 days after layering, respectively.

The treatment combination of $\mathrm{N}_{4} \mathrm{~W}_{2}$ (NAA @ $125 \mathrm{ppm}+$ Black poly wrapper) was recorded significantly maximum 0.140 and $0.247 \mathrm{~g}$ dry weight of roots followed by $\mathrm{N}_{3} \mathrm{~W}_{2}$ (NAA @ $100 \mathrm{ppm}+$ Black poly wrapper) (0.097 and $0.213 \mathrm{~g}$ ) and $\mathrm{N}_{4} \mathrm{~W}_{3}$ (NAA @ $125 \mathrm{ppm}+$ Blue poly wrapper) $(0.077$ and $0.190 \mathrm{~g})$, while, the minimum 0.013 and $0.057 \mathrm{~g}$ dry weight of roots were recorded in the treatment combination of $\mathrm{N}_{1} \mathrm{~W}_{1}$ (NAA @ $50 \mathrm{ppm}+$ White poly wrapper) at 30 and 60 days after layering, respectively. This may be due to increased synthesis and accumulation of growth promoting substance as well as availability of more nutrients under this treatment, which enhance the dry weight of roots.

As regards to concentrations of NAA, treatment $\mathrm{N}_{4} \quad$ (NAA $125 \mathrm{ppm}$ ) was significantly superior and recorded highest $61.12 \%$ rooting followed by $\mathrm{N}_{3}$ (NAA 100 ppm) (51.53\%) as compared to other treatment, while, it was observed lowest $35.39 \%$ rooting in the treatment NAA $50 \mathrm{ppm}$ $\left(\mathrm{N}_{1}\right)$ (Table 2). Similar findings were also reported by Shrivastava (2000), Tomar (2011), Singh and Pathak (2012) and Raut et al., (2015).

Significantly highest $54.79 \%$ rooting was observed under the treatment $\mathrm{W}_{2}$ (Black poly wrapper) and lowest $42.64 \%$ rooting in the treatment $\mathrm{W}_{1}$ (white poly wrapper). Black polythene significantly increased the percentage of rooting in minimum period in comparison to other treatment. It can be use successfully to hold moisture with rooting media around the part to be rooted and the same time covered by layered area to protect against damage as well as keeping the portion from becoming too hard. Similar findings were also reported by Patel et al., (1989), Baghel (1989) and Verma and Patel (2004).

Amongst interaction of both the factor, the treatment combination of $\mathrm{N}_{4} \mathrm{~W}_{2}$ (NAA @ 125 ppm + Black poly wrapper) was recorded significantly highest $65.63 \%$ rooting followed by $\mathrm{N}_{3} \mathrm{~W}_{2}$ (NAA @ 100 ppm + Black poly wrapper) (60.97\%) and $\mathrm{N}_{4} \mathrm{~W}_{3}$ (NAA @ 125 ppm + Blue poly wrapper) $(58.07 \%)$, while, the lowest $30.57 \%$ rooting was recorded in the treatment combination of $\mathrm{N}_{1} \mathrm{~W}_{1}$ (NAA @50 $\mathrm{ppm}+$ White poly wrapper). This may be due to increased level of growth promoting substances, available nutrients with the application $125 \mathrm{ppm}$ NAA. Similar findings were also reported by Sen et al., (1972) and Yeboah et al., (2014).

It is evident from the results (Table 2) that the survival percentage gradually increased in concentrations of NAA $\mathrm{N}_{1}$ to $\mathrm{N}_{4}$. Treatment $\mathrm{N}_{4}$ (NAA $125 \mathrm{ppm}$ ) was recorded highest $47.31 \%$ survival followed by $\mathrm{N}_{3}$ (NAA 100 ppm) $(40.74 \%)$ as compared to other treatment, while, it was observed lowest $33.52 \%$ survival in the treatment NAA $50 \mathrm{ppm}$ $\left(\mathrm{N}_{1}\right)$ at 60 days after planting of airlayering. These findings are in agreement with the findings of Tomar et al., (1999a), Shrivastava (2000), Tomar (2011), Patel et al., (2012), Singh and Pathak (2012) and Raut et al., (2015).

Significantly highest $43.75 \%$ survival was observed under the treatment $\mathrm{W}_{2}$ (Black poly wrapper) and lowest $37.10 \%$ survival in the treatment $\mathrm{W}_{1}$ (white poly wrapper) at 60 days after planting of air-layering. 
Similar findings were also reported by Patel $e t$ al., (1989) and Baghel (1989) reported that this beneficial response obtained by black polythene may be due to effect of etiolation.

Amongst interaction of both the factor, the treatment combination of $\mathrm{N}_{4} \mathrm{~W}_{2}$ (NAA @ 125 ppm + Black poly wrapper) was recorded significantly highest $50.93 \%$ survival followed by $\mathrm{N}_{3} \mathrm{~W}_{2}$ (NAA @ 100 ppm + Black poly wrapper) (46.30\%) and $\mathrm{N}_{4} \mathrm{~W}_{3}$ (NAA @ 125 ppm + Blue poly wrapper) $(46.17 \%)$, while, the lowest $32.30 \%$ survival was recorded in the treatment combination of $\mathrm{N}_{1} \mathrm{~W}_{1}$ (NAA @ $50 \mathrm{ppm}+$ White poly wrapper) at 60 days after planting of air-layering.

This may be due to increased level of growth promoting substances, available nutrients with the application $15000 \mathrm{ppm}$ IBA. Similar findings were also reported by Sen et al., (1972), Singh (2001) and Yeboah et al., (2014).

The economics of air layers was worked out on the basis of 1000 layers considering the cost of media, growth regulators i.e. NAA, different colour poly wrappers, materials for air layer, as well as labour cost.

It is revealed from the data (Table 3) obtained that the total cost and net CBR for making 1000 air layers were ranged from Rs. 5800.40 to Rs. 5901.00 with net return varied from Rs. 7019.60 to Rs. 14559.00 and C:B ratio between 1: 2.19 to $1: 3.51$. The maximum net return of Rs 14559.00 and highest cost benefit ratio 1: 3.51 was recorded in treatment $\mathrm{N}_{4} \mathrm{~W}_{2}$ (NAA@ 125 ppm + Black poly wrapper).

While, least net return of Rs 7019.60 and cost benefit ratio (1:2.19) was observed in treatment $\mathrm{N}_{1} \mathrm{~W}_{1}$ (NAA @ $50 \mathrm{ppm}+$ White poly wrapper) due to low plant survival and expenditure as compared to other treatments. These findings are in agreement with the findings of Azad and Matin (2015), Mali et al., (2015) and Soni et al., (2015).

\section{References}

Anonymous (2017). Horticulture statistics at a glance 2017. Published by Department of Agriculture, Cooperation and Farmers Walfare, Ministry of Agriculture and Farmers Walfare, Govt. of India. pp. 185.

Azad, Md. Salim and Matin, Md. Abdul (2015). Effect of Indole-3-Butyric Acid on clonal propagation of Swietenia macrophylla through branch cutting. Journal of Botany. Volume 2015, Article ID 249308, 1-7.

Baghel, K.S. (1989). Effect of plant growth substances and polythene wrapper on air-layering of different varieties of Mango (Mangifera indica L.). Unpublished thesis submitted to J.N.K.V.V. Jabalpur for the degree of M.Sc. (Ag.).

Hartmann, H.T. and Kester, D.E. (1972). Plant propagation: Principles and practices. Practice Hall of India New Delhi 3 (9): 270.

Majumdar, P.K. and Mukherjee, S.K. (1968). Guava a new vegetative propagation method. Indian Horticulture, (12): 1135.

Mali,D.S.; Ranpise,S.A.; Shirsath, H.K. and Kharde, R.P. (2015). Effect of pruning techniques on yield and economics in high density plantation of guava cv. Sardar. International Journal of Tropical Agriculture. 33 (4): 27312734.

Panse, V.C. and Sukhatme P.V. (1985). Statistical methods for agricultural workers. ICAR Publications, New Delhi. pp 155.

Patel, D.M.; Nehete, D.S.; Jadav R.G. and Satodiya B.N. (2012). Effect of PGR's and rooting media on air layering of 
different pomegranate (Punica granatum L.) cultivars. The Asian Journal of Horticulture. 7 (1): 89-93.

Patel, R.M.; Patel, R.B. and Patel, M.P. (1989). Effect of growth regulators and on rooting of air layers of guava. Bhartiya Krishi Anusandhan Patrika. 4(3):145-148.

Raut, U.A.; Jadhav, G.G.; Bhogave, A.F. and Deshmukh, M.S. (2015). Effect of different IBA levels on air layering of karonda (Carissa carandas L.). Research on Crops. 16 (3): 537-541.

Sen, P.K.; Bose,T.K. and Chakraborty, S.P. (1972). Effect of growth regulators on air-layering of cashew. Tropical and subtropical symposium. Plant Sciences. 12 (2): 535-538.

Shrivastva, P.K. (2000). Effect of growth regulators in combination and different rooting media on rooting and survival of air layers of Guava (Psidium guajava L.) var. Gwl.-27. Unpublished thesis submitted to JNKVV, Jabalpur for the M.Sc. (Ag.) Degree.

Singh, D. and Pathak, S (2012). Effect of IBA and NAA on propagation of Barbados cherry through layering. Crop Res. 43 (1, 2 \& 3): 120-122.

Singh, M. (2001). Efficacy of plant growth regulators, and their concentration and wrapper on rooting success and survival of air-layered guava twigs. Crop Research Hissar. 21 (2): 153 156.

Soni, Nitin; Pandey,S.K.; Singh, S.S.; Singh, S.R.K.; Mishra, A.; Baghel S.S. and
Kaurav, Pavan Kumar (2015). Production of true- to-type guava plants through clonal propagation. International Journal of Applied and Pure Science and Agriculture. 1 (12): 131-136.

Tomar, K.S.; Gurjar, B.S. and Tomar R.S. (1999a). Study on the effect of wood maturity and IBA on asexual propagation of kagzi lime (Citrus aurantifolia Swingle) by air layering. Advances in Plant Sciences. 12 (2): 583-588.

Tomar, Y.K. (2011). Effect of various concentrations of bio-regulators and time of airlayering on the multiplication of jackfruit (Artocarpus heterophyllus Lam.). International Journal of Current Research. 33 (6): 316-318

Verma, L.R. and Patel, K.B. (2004). Effect of etiolation and various concentration of IBA on air layering in guava cv. Dholka. Abstracts of first Indian Horticulture Congress held at New Delhi, 6- $9^{\text {th }}$ Nov. 2004. pp140.

Yeboah Julius; Ben Kwaku Branoh Banful; Peter Yaw Boateng; Frank Manu Amoah; Bonaventure Kissinger Maalekuu and Samuel Tetteh Lowor (2014). Rooting response of airlayered shea (Vitellaria paradoxa) trees to media and hormonal application under two different climatic conditions. American Journal of Plant Sciences. 5: 1212-1219.

\section{How to cite this article:}

Vikas Mandloi, Rajesh Lekhi, Devendra Vishvkarma and Amit Patel 2019. Effect of Naphthalene Acetic Acid and Colour Poly Wrappers on Rooting, Survival and Economics of Air Layring of Guava (Psidium guajava L.) cv. Gwalior 27. Int.J.Curr.Microbiol.App.Sci. 8(09): 1525-1534. doi: https://doi.org/10.20546/ijcmas.2019.809.175 